\title{
PENENTUAN DOSIS FORMULASI PUPUK ORGANIK UNTUK EFISIENSI PENGGUNAAN PHONSKA PADA TANAMAN JAGUNG MANIS (Zea mays sacharata Sturt.)
}

\author{
DETERMINING ORGANIC FERTILIZER FORMULATION FOR MORE EFFICIENT USE OF \\ PHONSKA ON SWEET CORN (Zea mays saccharata Sturt.)
}

\author{
Antje Grace Tulungen*, Pemmy Tumewu*, Maria Montolalu**, John L. Rantung*, Stella. M. \\ Th. Tulung* \\ *)Jurusan Budidaya Pertanian, Fakultas Pertanian Unsrat Manado, 95115 \\ *)Jurusan IImu Tanah, Fakultas Pertanian Unsrat Manado, 95115
}

\begin{abstract}
The use of organic fertilizer provides soil with macronutrients, micronutrients, and organic acids which improve the long-term physical, chemical, and biological fertility of the soil. This research aims to: 1) Increase physical and chemical soil fertility, 2) Acquire the interaction between organic fertilizer and Ponska fertilizer dosage on sweet corn crops, 3) Acquire the most efficient dosage of PONSKA fertilizer on sweet corn, and 4) disseminate research results through journal articles and directly to farmers. This research will increase the efficiency of NPK Ponska chemical fertilizers by utilizing waste from around the farm and lakes to formulate organic fertilizer to apply on sweet corn crops and as a reference to teaching material. Factorial research with two factors was designed using a randomized block design. Factor $I(A)=$ Organic fertilizer formulation, comprising of $A 1=20$ ton/ha, $A 2=30$ ton/ha, and $A 3=40$ ton/ha. Factor $I I(B)=$ Phonska fertilizer, comprising of $B 1=25 \%$ Ponska, and B2 $=50 \%$ Ponska. Every treatment was replicated four times, yielding 24 research plots. Response variables observed were: Plant height, number of leaves, dry weight of the plant. Data were analyzed using ANOVA, followed by Tukey's honest significance difference test (alpha $=0.05$ ) if significant differences were found. Results showed that the interaction between organic and Phonska fertilizer formulations had significant effects on plant height. A dosage of 40 ton/ha of organic fertilizer can decrease the use of phonska fertilizer by $75 \%$ based on the height of sweet corn plants.
\end{abstract}

Keywords: Organic fertilizer formulations, sweet corn, PHONSKA NPK fertilizer efficiency

\section{ABSTRAK}

Penggunaan pupuk organik ke dalam tanah dimaksudkan sebagai sumber hara makro, mikro dan asam-asam organik, untuk memperbaiki kesuburan fisik, kimia dan biologi tanah dalam jangka panjang. Tujuan penelitian adalah : 1) Meningkatkan kesuburan fisik dan kimia tanah, 2) Memperoleh interaksi antara dosis formulasi pupuk organik dan pupuk Ponska di pertanaman jagung manis, 3) Memperoleh ketepatan besaran efisien pupuk PONSKA pada tanaman jagung manis, 4) Menyebarkan informasi hasil penelitian ini melalui jurnal dan informasi langsung ke petani. Manfaat Penelitian, untuk efisiensi penggunaan pupuk kimia NPK Ponska dengan memanfaatkan limbah yang ada disekitar kebun, danau dan peternakan sebagai formulasi pupuk organik untuk diaplikasikan pada tanaman jagung manis dan sebagai salah satu bahan acuan dalam bahan ajar.Percobaan factorial dirancang menggunakan Rancangan Acak Kelompok yang terdiri dari dua factor. Faktor I $(A)=$ Formulasi Pupuk Organik, terdiri dari $A 1=20$ ton/ha formulasi pupuk organik, $A 2=30$ ton/ha formulasi pupuk organik, $A 3=40$ ton/ha formulasi pupuk organik. Faktor II $(B)=$ Pupuk Phonska, Terdiri dari B1 $=25 \%$ Ponska, dan B2 = 50\% Ponska, Setiap perlakuan diulang empat kali sehingga diperoleh 24 petak percobaan. Variabel respons yang diamati meliputi :Tinggi tanaman, Jumlah daun, Berat kering tanaman,. Data dianalisis menggunakan analisis ragam dan jika terdapat pengaruh perlakuan dilanjutkan dengan menggunakan Uji Beda Nyata Jujur (BNJ) pada taraf uji $5 \%$. Hasil penelitian menunjukan bahwa interaksi antara formulasi pupuk organik dan dan pupuk phonska berpengaruh nyata terhadap tinggi tanaman. 40 ton/ha Formulasi pupuk organik dapat mengurangi penggunaan pupuk phonska sebesar $75 \%$ pada parameter tinggi tanaman jagung manis.

Kata kunci: Formulasi pupuk organik, jagung manis, efisiensi pupuk NPK Phonska 


\section{PENDAHULUAN}

Peningkatan produksi pertanian menjadi perhatian utama karena banyak lahan pertanian sudah mengalami pemadatan sehingga kesuburan fisik, kimia, maupun biologi menurun. Keadaan ini berakibat pada turunnya produksi atau hasil panen. Hal ini disebabkan penggunaan pupuk kimia (anorganik) NPK pada setiap musim tanam. Penggunaan pupuk kimia yang terus menerus juga telah terbukti dapat menyebabkan kerusakan tanah dan pencemaran lingkungan. Tanah menjadi cepat mengeras, kurang mampu menyimpan air dan cepat menjadi asam yang pada akhirnya akan menurunkan produksivitas tanaman (Parman, 2007). Oleh karena itu, perlu dikembangkan teknologi alternatif dalam upaya peningkatan hasil tanaman.

Dewasa ini banyak dijual pupuk NPK majemuk seperti phonska dan NPK kenari dengan komposisi $\mathrm{N}, \mathrm{P}$, dan $\mathrm{K}$ berbeda. Hasil penelitian, dosis pupuk NPK majemuk untuk tanaman jagung manis $300-400 \mathrm{~kg} / \mathrm{ha}$. Penggunaan pupuk anorganik mempunyai beberapa kelemahan yaitu antara lain harga relatif mahal, dan penggunaan dosis yang berlebihan dapat menyebabkan pencemaran lingkungan apalagi kalau penggunaannya secara terusmenerus dalam waktu lama, dapat menyebabkan produktivitas lahan menurun, karena terjadi degradasi atau penurunan kesuburan tanah. Tanah menjadi cepat mengeras, kurang mampu menyimpan air dan cepat menjadi asam yang pada akhirnya akan menurunkan produktivitas tanaman. Sebab itu, perlu dikembangkan teknologi alternatif dalam upaya peningkatan hasil tanaman dan penurunan ketergantungan terhadap pupuk anorganik (kimia). Teknologi tersebut haruslah secara ekonomi terjangkau dan secara teknologi mudah diaplikasikan. Alternatif teknologi yang dapat diterapkan adalah penggunaan pupuk bokashi dalam proses budidaya tanaman.

Tanaman jagung manis membutuhkan hara dengan dosis $200 \mathrm{~kg} \mathrm{~N}$ atau setara dengan 435 urea ha $^{-1}, 150 \mathrm{~kg} \mathrm{P}_{2} \mathrm{O}_{5}$ ha- $^{-1}$ setara dengan 335 kg TSP ha-1 dan $150 \mathrm{~kg} \mathrm{~K}_{2} \mathrm{O} \mathrm{ha}^{-1}$ setara dengan $250 \mathrm{~kg} \mathrm{KCl} \mathrm{ha}^{-1}$ serta bahan organik 10 sampai 20 ton per hektar (Anonimous, 1992; Koswara, 1989). Jumlah hara untuk tanaman jagung manis cukup besar, sebab itu untuk memenuhi kebutuhan tersebut perlu dicari teknologi yang dapat menggantikan ataupun untuk substitusi sehingga kebutuhan pupuk kimia dapat dikurangi. Pupuk bokashi dapat meningkatkan kesuburan fisik, kimia, dan biologi tanah serta memacu pertumbuhan tanaman.

Pupuk bokashi merupakan pupuk organik menggunakan teknologi fermentasi dengan bahan baku penyusunnya bersumber dari makhluk hidup, seperti sisa tumbuhan, hewan, dan manusia. Kualitas pupuk organik sangat ditentukan oleh komposisi bahan bakunya. Secara teknis, proses pembuatan pupuk organik lebih mudah dibandingkan dengan pembuatan pupuk anorganik, sehingga proses produksinya banyak dilakukan dalam skala industri rumahan, namun komposisinya tidak jelas, aspek kimia, fisik, dan biologi terabaikan dan pada akhirnya menghasilkan produk yang berkualitas rendah. Rendahnya pengawasan terhadap kualitas pupuk organik di pasaran disinyalir telah menyebabkan tumbuh suburnya produsen pupuk organik. Untuk menjamin kualitas pupuk organik, petani bisa membuat sendiri sehingga dapat dikontrol namun diperlukan teknologi tepat guna dan tepat sasaran.

Pupuk organik berpengaruh terhadap sifat kimia tanah adalah kandungan humusnya. Adanya asam humat yang dapat melarutkan besi dan aluminium, menyebabkan senyawa fosfat akan lepas dan menjadi senyawa fosfat yang lebih sederhana dalam bentuk tersedia yang dapat diserap tanaman. Dengan demikian pupuk organik dapat meningkatkan kesuburan tanah (Simamora dan Salundik, 2006).

Pupuk organik dari berbagai sumber bahan organik berfungsi sebagai gudang penyimpan hara, juga mudah melepaskan hara tersebut untuk dipakai oleh tanaman. Fosfat yang 
semula terfiksasi $\mathrm{Ca}$, Fe dan Al dan tidak dapat diserap tanaman akan menjadi tersedia bila unsur-unsur $\mathrm{Ca}$, Fe dan Qal tersebut, diikat bahan organik menjadi organo-kompleks. Proses ini adalah proses kimia, sehingga kelarutan Al dan Fe dalam tanah yang semula tinggi dan bersifat racun dapat dikurangi. Bahan dasar pupuk organik banyak ditemui di alam sekitar tempat tinggal atau di kebun. Pupuk organik merupakan pupuk yang berasal dari bahan yang sebagian besar berasal dari tanaman atau hewan yang telah melalui proses rekayasa untuk menyediakan hara terutama $\mathrm{N}$ dan C-organik, serta memperbaiki sifat fisik, kimia dan biologi tanah. Pupuk organik dapat dibuat dari berbagai jenis bahan dasar seperti sisa panen tanaman padi, jagung, tebu, kelapa (jerami, brangkasan, tongkol jagung, bagas tebu, sabut kelapa), serbuk gergaji, kotoran hewan, limbah media jamur, limbah pasar, rumah tangga, dan pabrik, serta gulma (tumbuhan liar) baik yang hidup di darat maupun di air seperti eceng gondok, Hydrilla verticillata, Chromolaena odorata (krinyuh). Karena bahan dasar pembuatan pupuk organik sangat bervariasi, maka kualitas pupuk yang dihasilkan sangat beragam sesuai dengan kualitas bahan dasar. Pupuk organik dari beberapa bahan organik dipadukan untuk mendapatkan satu formulasi yang dapat memberikan pertumbuhan dan produksi tanaman jagung terbaik. Penggunaan formulasi pupuk organik dapat mengurangi dosis pupuk NPK pada tanaman jagung manis. Hasil penelitian Tumewu, Montolalu, dan Tulungen (2017) Substitusi Formulasi Pupuk Organik Untuk efisiensi Penggunaan Pupuk Anorganik Phonska pada Tanaman Jagung Manis (Zea mays saccharata Sturt) dengan formulasi pupuk organik Hydrilla verticillata+pupuk kotoran sapi+kotoran ayam dosis 20 ton/ha mampu menurunkan setengah dosis Phonska (dosis rekomendasi) terhadap bobot tongkol jagung manis. Ini berarti terjadi efisien penggunaan pupuk anorganik Phonska sebesar $50 \%$ dari dosis rekomendasi $300 \mathrm{~kg} / \mathrm{ha}$ menjadi $150 \mathrm{~kg} / \mathrm{ha}$. Perlu dilakukan penelitian apakah dosis phonska masih bisa di turunkan sampai $25 \%$ dari dosis rekomendasi. Untuk itu penelitian ini penting dilakukan dengan tujuan mempelajari sampai berapa dosis formulasi pupuk organik untuk efisien pupuk phonska.

\section{METODE PENELITIAN}

\section{Tempat dan Waktu Penelitian}

Penelitian dilaksanakan di Kebun Percobaan Fakultas Pertanian Unsrat dan laboratorium Tanah Balitpalma Mapanget Manado sejak bulan Maret sampai desember 2018.

\section{Bahan dan Alat}

Bahan dan alat yang digunakan adalah : Benih Jagung manis Secada, Hydrilla verticillata, kotoran sapi dan ayam, EM4, Dedak, Gula, Sekam, EM4, timbangan, bambu, plastic meteran, penampung air, alat tulis menulis, dan lain-lain.

\section{Rancangan Percobaan}

Percobaan factorial dirancang menggunakan Rancangan Acak Kelompok yang terdiri dari dua factor. Faktor I $(A)=$ Formulasi Pupuk Organik, terdiri dari $\mathrm{A} 1=20$ ton/ha, $\mathrm{A} 2=30$ ton/ha, $\mathrm{A} 3=$ 40 ton/ha. Faktor II (B) = Pupuk Phonska, Terdiri dari B1 $=25 \%$ Phonska dan B2 $=50 \%$ Phonska. Setiap perlakuan diulang empat kali sehingga diperoleh 24 petak percobaan.

\section{Variabel Respon}

Variabel respons yang diamati meliputi : Tinggi tanaman, Jumlah daun, dan Berat kering tanaman.

\section{Analisis Data}

Data dianalisis menggunakan analisis ragam dan jika terdapat pengaruh perlakuan dilanjutkan dengan menggunakan Uji Beda Nyata Jujur (BNJ) pada taraf uji $5 \%$. 


\section{Prosedur Kerja Penelitian}

1) Membuat formulasi pupuk organik bahan Hydrilla verticillata, kotoran sapi dan kotoran ayam (menggunakan activator EM4). Masing-masing dengan perbandingan $1: 1: 1$. Pembuatan formulasi pupuk organik dengan system fermentasi menggunakan EM4 yang dilarutkan bersama gula pasir kedalam 20 liter air kemudian dicampurkan ke formulasi bahan organik sesuai penetapan dalam perlakuan. Formulasi bahan organik ditutup dengan terpal kemudian suhu dikontrol setiap hari sambil formulasi pupuk organik dibolak balik. Dua minggu formulasi pupuk organik sudah bisa diaplikasikan.

2) Analisis fisik dan kimia tanah awal serta analisis kimia untuk pupuk organik di laboratorium Jurusan Tanah.

3) Pengolahan tanah dengan sedalam kurang lebih $\quad 30 \mathrm{~cm}$ sambil membersihkan rumput-rumputan (gulma).

4) Pembuatan petakan dengan ukuran $2 \mathrm{~m}$ x $3 \mathrm{~m}$ sebanyak 24 petakan. Jarak antar blok (ulangan) 1 meter dan jarak antar petak $75 \mathrm{~cm}$.

5) Pemupukan dengan formulasi pupuk organik sesuai dosis perlakuan dilakukan tiga hari sebelum tanam benih, pemberian setengah dosis pupuk Ponska diberikan pada saat tanam benih jagung manis dan setengah dosis diberikan kembali pada saat tanaman jagung manis berumur 28 hari setelah tanam jagung manis.

6) Penanaman benih jagung manis dengan jarak tanam $25 \mathrm{~cm} \times 75 \mathrm{~cm}$.

7) Penyiangan gulma pada umur tanaman 21 hari setelah tanam sekaligus pemupukan susulan dan pembumbunan.

8) Pemeliharaan tanaman meliputi penyiraman dilaksanakan dua kali dalam sehari karena tidak ada hujan selama penelitian (musim kemarau) dan pemasangan turus pada tanaman jagung manis menghindari tanaman rebah (patah) akibat angin kencang.

9) Pengambilan data sesuai variabel yang diamati.

10) Panen pada saat tanaman rambut pada tongkol jagung manis sudah berwarna kecoklatan.

\section{HASIL DAN PEMBAHASAN}

Pertumbuhan tanaman jagung manis meliputi tinggi tanaman, jumlah daun dan berat kering tanaman jagung manis. Hasil analisis statistik menunjukan bahwa terdapat interaksi antara formulasi pupuk organik dan pupuk phonska terhadap tinggi tanaman jagung manis. 


\section{Figure 1. Effects of different organic fertilizer and PHONSKA formulations towards the height of sweet corn plants}

$25 \%$ Dosis Phonska $\quad 50 \%$ Dosis Phonska

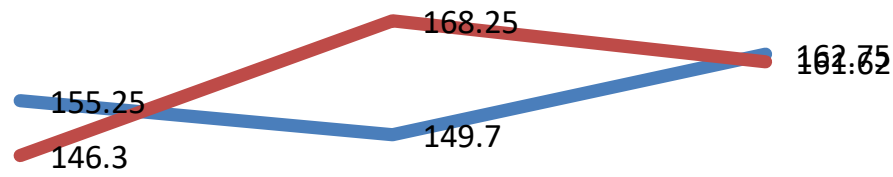

20 ton Formulasi Pupuk 30 ton Formulasi Pupuk 40 ton Formulasi Pupuk Organik/ha Organik/ha\% Organik/ha

Interaksi Formulasi pupuk organik dosis 40 ton/ha pada $25 \%$ Phonska yaitu $75 \mathrm{~kg} / \mathrm{ha}$ memberikan tinggi tanaman paling baik. Menurut Setiawan (1993), pertumbuhan, produksi dan mutu hasil jagung manis dipengaruhi oleh dua faktor yaitu faktor genetik dan faktor lingkungan seperti kesuburan tanah. Pemberian pupuk organik maupun anorganik dapat meningkatkan kesuburan tanah. Keunggulan pupuk organik akan menciptakan kodisi fisik, kimia dan biologi tanah semakin baik. Fisik tanah yang baik memudahkan akar untuk berkembang, menyebabkan jangkauan akar lebih dalam dan luas sehingga meningkatkan hara diserap oleh tanaman. Menurut Myrna (2006), tersedianya N pada awal pertumbuhan akan mempengaruhi luas daun yang terbentuk yang pada fase berikutnya akan mempengaruhi penyerbukan dan pengisian biji. Unsur hara $\mathrm{N}$ yang terdapat pada formulasi pupuk organic (Tabel 1) dan phonska akan mendorong pertumbuhan organ-organ yang berkaitan dengan fotosintesis, yaitu daun. Tanaman yang cukup mendapat suplai $\mathrm{N}$ akan membentuk helai dan yang luas dengan kandungan klorofil tinggi, sehingga tanaman dapat menghasilkan asimilat dalam jumlah cukup untuk menopang pertumbuhan vegetatif. Pupuk kandang ayam sebagai pencampur dalam formulasi pupuk organik berparan dalam menyediakan unsur hara. Menurut Syekhfani (2000), pupuk kandang memiliki sifat yang alami dan tidak merusak tanah, menyediakan unsur makro dan mikro. Selain itu pupuk kandang berfungsi untuk meningkatkan daya menahan air, aktivitas mikrobiologi tanah, nilai kapasitas tukar kation dan memperbaiki struktur tanah.

Table 1. Lab results of organic fertilizer formulation analysis

\begin{tabular}{|c|c|c|c|c|c|c|}
\hline Analisis & $\begin{array}{c}\text { Kadar Air } \\
(\%)\end{array}$ & $\mathrm{pH}$ & $\mathrm{C}(\%)$ & $\mathrm{N}(\%)$ & P (ppm) & K (\%) \\
\hline $\begin{array}{c}\text { Formulasi } \\
\text { Pupuk Organik }\end{array}$ & 9,89 & 7,25 & 10,69 & 1,18 & 0,51 & 1,42 \\
\hline
\end{tabular}

Sumber: Laboratorium Balitpalma, 2018 
Pemberian formulasi pupuk organik dan pupuk phonska saling melengkapi hara yang ada disamping itu terjadi peningkatan kualitas tanah secara fisik, kimia dan biologi. Sebab itu penggunaan formulasi pupuk organik yang tepat dapat mengurangi penggunaan pupuk kimia serta memberikan hasil jagung manis yang optimum. Pemberian pupuk organik dapat menggantikan atau mengurangi penggunaan pupuk anorganik secara terus menerus karena dapat merusak sifat fisik, kimia dan biologi tanah. Seperti yang dikemukakan Rima, dkk, (2012), bahwa bahan organik dalam tanah berperan penting dalam memperbaiki sifat fisik, kimia, dan biologis tanah sehingga dapat menjaga dan meningkatkan kesuburan tanah, serta mengurangi ketergantungan pada pupuk anorganik. Hasil penelitian Martajaya dkk., (2009) menunjukkan bahwa pemberian paitan dalam kurun waktu seminggu sebelum tanam pada tanam jagung manis dapat menghasilkan bobot segar tongkol tertinggi dibandingkan perlakuan lainnya yaitu sebesar 8,5 ton/ha. Menurut Siagian dan Harahap (2001), pemupukan dengan pupuk organik tanpa pupuk NPK kurang mendukung pertumbuhan tanaman, akan tetapi kombinasi pupuk organik dengan pupuk NPK memberikan hasil pertumbuhan yang tinggi dan terbaik.

\section{KESIMPULAN}

40 ton/ha Formulasi pupuk organik dapat mengurangi penggunaan pupuk phonska sebesar $75 \%$ pada parameter tinggi tanaman jagung manis.

\section{DAFTAR PUSTAKA}

Anonimous, 1992. Hasil Penelitian Tanaman Pangan. Prosiding Seminar Balittan

Bogor. 29 Pebruari dan 2 Maret 1992. Volume 1. Badan Penelitian dan

Pengembangan Pertanian Balai Penelitian Tanaman Pangan Bogor.
Arnon. I, 1975. Mineral Nutrition of Maize. Int. Potash. Ints. Worbloufen. Bern Switzerland.

Bordovsky, D.G., M. Choudhary, dan C.J. Gerad. 1999. Effect of tillage, cropping, and

residue management on soil properties in the Texas Rolling Plains. Soil Science: 331-

340.

Brady, N. C. 1974. The Nature and Properties of Soils. 8 th edition. MacMillan

Publishing Co. Inc. New York.

Chariatma, A.J. 2008. Pengaruh Berbagai Dosis Pupuk Kotoran Ayam dan NPK (15: 15 :

15) Terhadap Pertumbuhan dan Hasil Tanaman Kacang Panjang (Vigna sinensis. L).

Skripsi. Fakultas Pertanian Universitas Andalas Padang.

Fathan, R., M. Rahardjo, A. K. Makarim. 1988. Hara Tanaman Jagung. Dalam

Jagung. Penyuntuing Subandi, M. Syam, Adi Widjono. Badan Penelitian

Pengembangan Pertanian. Pusat Penelitian dan Pengembangan Tanaman Pangan

Bogor.

Gardner, F.P., R.B. Pearce dan R.L. Mitchell, 1991. Fisiologi Tanaman Budidaya. Universitas Indonesia. Jakarta.

Hairiah, K., H., Widianto ., S.R. Utami., D. Suprayogo ., Sunaryo., S.M. Sitompul., B. Lusiana., R. Mulia ., M.Van Noordwijk dan G. Cadisch, 2000. 
Pengelolaan Tanah Masam Secara Biologi. ICRAF. Bogor.

Koswara, J. 1989. Budidaya Jagung Manis. Makalah dibawakan dalam Kursus

Singkat Hortikultura BKS Barat USAID di UNILA; 24 Juli - 12 Agustus 1989.

Martajaya, M., L. Agustina dan Syekhfani. 2009. Pertumbuhan dan Hasil Jagung Manis

(Zea mays Saccharata Sturt) yang Dipupuk Beberapa Macam Pupuk Organik pada

Saat yang Berbeda terhadap Anorganik. Crop Agro J. IImiah Budidaya Pertanian. 2 (2) : 90 102.

Parman, S. 2007. Pengaruh Pemberian Pupuk Organik Cair terhadap Pertumbuhan dan

Produksi Kentang (Solanum tuberosum L.). Anatomi dan Fisiologis.

Myrna, N.E.F. 2006. Hasil Tanaman Jagung Pada Berbagai Dosis dan Cara Pemupukan N

Pada Lahan Dengan Sistem Olah Tanah Minimum. J. Agronomi 9 (1).

Rima. P,. Busyra. BS,. Hendri. P., dan Syafri. E., 2012. Kajian Pemanfaatan Kompos

Tandan Kosong Kelapa Sawit Sebagai Subsitusi Pupuk Kalium Mendukung

Pertanian Sayuran Organik di Provinsi Jambi. Kementrian Riset dan Teknologi.

Lapoaran Akhir Insentif Peningkatan Peneliti Dan Perekayasa. 29 hal. Diakses 19

Oktober 2018.

Setiawan, K., 1993. Pertumbuhan, produksi dan kadar sukrosa tiga varietas tiga varietas jagung manis akibat pemberian berbagai taraf dosis urea. J. Hortikultura Vol 3 No. 12. Jakarta.

Syekhfani. 2000. Sifat dan Fungsi Pupuk Kandang. http://etd.eprints.ums.ac.id/

14422/2/BAB_I.pdf. [ 15Agustus 2018]

Siagian, M.H. dan R. Harahap. 2001. Pengaruh pemupukan dan populasi tanaman jagung terhadap produksi baby corn pada tanah podsolik merah kuning. Jurnal penelitian UMJ, Vol 7 (3). Sept 2001: $331-340$

Tumewu,P. A.G. Tulungen, M. Montolalu. 2017. Substitusi Formulasi Pupuk Organik

Untuk Efisiensi Penggunaan Pupuk Anorganik Phonska Pada Tanaman Jagung

Manis (Zea mays saccharata Sturt) Laporan Penelitian RTUU Tahun 2017. 